\title{
DLL4 Gene
}

National Cancer Institute

\section{Source}

National Cancer Institute. DLL4 Gene. NCI Thesaurus. Code C90317.

This gene is involved in the notch signal transduction pathway. 